\title{
The use of commercial mediation as alternative dispute resolution tool in the Czech Republic, Hungary and Slovakia
}

\section{Употреба комерцијалне медијације као алтернативног алата за решавање спорова у Чешкој, Мађарској и Словачкој}

\author{
József Poór \\ J. Selye University, Komárno, Slovakia, e-mail: poorif@t-online.hu \\ Radka Lankašová \\ University of Economics, Czech Republic, e-mail: rlankasova@volny.cz \\ Allen D. Engle \\ Eastern Kentucky University, Richmond, USA, e-mail: allen.engle@eku.edu \\ Katalin Szabó \\ Szent Istvan University, Gödöllő,Hungary, e-mail: Szabo.Katalin@gtk.szie.hu \\ Ildikó Budavári-Takács \\ ELTE-University,Budapest, Hungary, e-mail: budavaritakacs89@gmail.com \\ Zoltán Šeben \\ J. Selye University, Komárno, Slovakia, e-mail: sebenz@ujs.sk \\ Róbert Korényi \\ ELTE-University,Budapest, Budapest, Hungary, e-mail: korenyi.robert@gmail.com \\ Péter Szitás \\ National Public University, Budapest, Hungary, e-mail: peter.szitas@gmail.com \\ Tímea Juhász \\ Economic University Budapest, Budapest, Hungary, e-mail: juhasz.timi@hotmail.com
}

\begin{abstract}
For a long time, various companies and organizations have used traditional courts or other legal tools to resolve different complex disputes or problems. However, numerous influencing factors often interrupted this formalized problem-solving approach. In the countries of the former Eastern bloc, under the former communist system, the Party often acted as mediator. This, of course, has changed totally since the political system has become democratic. Our study investigates conflict-solving styles, procedures and processes in Central Europe the Czech Republic, Slovakia and Hungary. The study done in 297 companies in these three countries show that conflicts between individuals, employees and the company are found most often, while problems between the local company and associated parent companies are less frequently found. Regardless of the country, companies have spent at least $10 \%$ of their working time dealing with internal conflicts. Some $79 \%$ of organizations focus on managing external conflicts for at least $10 \%$ of their working time, while around $9 \%$ of companies use mediation as a method of resolving conflict. The organizations in the study do not differ from country to country in terms of the use and success of mediation practices.
\end{abstract}

Corresponding author 
Keywords: conflict, conflict-management, mediation, commercial mediation, Czech Republic, Hungary and
Slovakia JEL classification: J28, J52

Сажетак: Дуго времена су разне компаније и организације користиле традиционалне судове или друге правне алате за решавање различитих сложених спорова или проблема. Међутим, бројни фрактори утицаја често су прекидали овај формализовани приступ решавању проблема. У земљама бившег источног блока, под бившим комунистичким системом, партија се често понашала као посредник. То се, наравно, потпуно променило откако је политички систем постао демократски. Наша студија истражује стилове, поступке и процесе решавања сукоба у централној Европи - посебно у Чешкој, Словачкој и Мађарској. 297 компанија које су проучаване у ове три земље показују да се сукоби између појединаца, запослених и предузећа налазе често, док се проблеми између локалне компаније и повезаних матичних компанија ређе налазе. Без обзира на земљу, компаније су провеле најмање 10\% свог радног времена бавећи се унутрашњим сукобима. Око 79\% организација фокусира се на управљање спољним сукобима током најмање $10 \%$ свог радног времена, док око 9\% компанија користи медијацију као метод решавања сукоба. Организације у студији се не разликују од земље до земље у погледу употребе и успеха праксе медијације

Кључне речи: сукоб, управљање сукобима, посредовање, комерцијално посредовање, Чешка, Мађарска и Словачка

JEЛ класификација: J28, J52

\section{Introduction}

According to the representatives of conflict theory, all human societies are fundamentally characterized by conflicts, which are necessarily a harmful phenomenon and do not promote social development. The main representatives were Plato, Marx and Engels, Weber, Pareto and Lenski (Lovász, 2009; Rössel, 2013). In contrast, there are representatives of the theory of harmony, whose human societies are fundamentally characterized by the cooperation of the members, the conflict is only extraordinary and dysfunctional. Representatives of the theory were Aristotle and Adam Smith.

For a long time, reference to divine providence and existence were the basis for solving problems (Treacy, 1948). Investing in confrontation wastes both time and energy and consumes resources originally meant for something else. Swift action is necessary if a conflict arises, otherwise the situation may lead to a deeper, escalating forms of confrontation (Yusuf \& Pretorius, 2017). If the unfavorable situation is prolonged and not managed correctly, the chance of concluding an agreement between the parties involved decreases rapidly (Patterson et al., 2011).

The number of individuals or groups involved in a dispute may vary. When an outside-party is asked for assisted negotiation, it might provide a solution acceptable by all impacted parties (Moore, 2003). Conflict-solving can be much more organizationally effective and cost-efficient compared to neglecting the problem or becoming involved in a long and expensive process of litigation.

This study focuses on the conflict-solving styles and procedures present in Central Europe, and it aims to compare the methods and processes of conflict-management in three post-socialist countries - the Czech Republic, Slovakia and Hungary. 
In the introductory part, the paper reviews the peer literature and defines the possible forms of facilitation available to resolve conflicted relationships, in particular focusing on the normal methods of conflict escalation and intervention strategies. This discussion is followed by the presentation of conflict-management procedures in the field of business activities with a special focus on the patterns and tendencies of the three countries investigated.

\section{Theoretical background}

\subsection{Organizational conflict}

The term conflict comes from the Latin word confligo, which means confront, oppose or counter. By organizational conflicts we mean the encounters that primarily occur at workplaces. These encounters are between individuals or groups and based on real or perceived differences in goals, means, preferences and perspectives (Kelly, 1970; Kathman \& Kathman, 1990; Stone et al., 2000). There are several types of conflict in an organization. The nature of conflict is either related to processes, tasks or relationships (Kurtzberg \& Mueller, 2005). With regard to conflict management, it is important to discuss the parties in conflict, the escalation of conflict, individual conflict-management strategies, the deepening of conflict and forms of more informal and more institutionalized mediation.

\subsection{The parties in conflict}

According to Griffin (2010, p. 597) "conflicts in an organization are either between or within groups". Conflicts within a group usually develop in an organizational unit between individuals, whereas conflicts between groups generally appear among horizontal (e.g. conflict between research \& development team and engineers) and vertical (e.g. middle and senior management) units in an organizational structure (Katz \& Kahn, 1966). Mastenbroek (1991) establishes four types of conflict relationship between groups:

- In the case of instrumental relationships, organizational units are bound by a certain structural and technical interdependence. This mutual dependence results in a tight cooperation in task distribution and coordination. This type of relationship facilitates logistics or formal decision-making processes. Conflicts usually emerge from different perceptions of short-term, operative goals and planning horizons.

- Socio-emotional relationships feature informal interpersonal relations. Conflicts are based on sympathy and antipathy.

- Power relations within an organization are connected to formal and informal positions, which have interest enforcement and manipulation potential. Conflicts are about the acquisition and utilization of power. 
- Negotiation relations develop between organizational units in connection with the division of limited resources. Fundamentally, the allocation of resources serves as the basis of conflict.

\subsection{Escalation of conflict}

Glasl (1999) describes nine stages of conflict escalation. Methods of intervention change as conflicts deepen. He points out that, after a certain stage, conflict resolution is only possible by involving third party mediators. According to Glasl (1999), escalation occurs in the following ways:

1. Hardening. Due to different positions (emotions, interests etc.), tension arises among the parties.

2. Debates. Preliminary discussions lead to verbal confrontation, which means open communication, debate and polemics between parties. At this stage, the parties can agree on a constructive solution.

3. Without words. As parties fail to resolve their conflicts in the previous stages, they usually choose to withdraw from direct interaction, maintain distance or cut $/ \mathrm{minimize}$ communication with the other party.

4. Coalition. Conflicting parties attempt to acquire allies and get them involved in the situation. These third party allies provide support; empowering the position of the supported party, this in turn leads to increased opposition and negative attitudes.

5. Loss of face. At this stage, parties initiate a psychological assault towards each other. Opposing parties try to draw the attention of their allies to the other party's false position (values, interest etc.). The goal of this behavior is to destroy the other party's face/authority in public.

6. Strategies of threats. The level of tension increases between the parties and, as a result, they want to force a solution. Hence, they declare an ultimatum against each other. These threats further deepen the conflict; however, it is still not a psychological stage.

7. Limited destructive blows. At stage seven disapproval increases further. Trust fully turns into mistrust. Both parties presuppose bad intentions on the part of the "other" so that violent measures can be justified. Forms of verbal (e.g. gossip) and physical (e.g. slap) aggression appear.

8. Fragmentation of the enemy - Aggression intensifies. The goal is to destroy the other party and its subsystems (allies, coalitions). The purpose of aggression is to force the other party to step out of the situation (e.g. quit the job, move from the neighborhood, divorce, physical destruction...etc.).

9. Together into the abyss. At the last stage, aggression between parties escalates to the point that they further increase their efforts to destroy the other at all costs. In extreme cases, risk of self-destruction becomes apparent. 
The first three stages can result in a win-win situation. It is possible to achieve a joint solution at this stage. Consequently, resolution of conflicts can bring satisfaction to both parties. In this case, conflict is constructive.

Stages four to six are called win-lose stages. A solution acceptable to both parties can only be obtained by using third party neutral mediators. A solution enforced by any of the parties means victory for one party and defeat for the other. These types of conflict are destructive.

Stages seven to nine are called lose-lose stages. It is difficult for parties to remain objective when they perceive that others disagree with or even disapprove of their point of view (Jehn, 1997). A solution that is acceptable to both parties can no longer be obtained by using third party, neutral mediators. Damage has been done and the only sensible goal is to mitigate any further losses. The only solution is through the involvement of outside authorities, such as court of law or the military. These types of conflict are clearly destructive.

Glasl's escalation model is an important diagnostic tool to understand conflict and sensitize people. Yasmi et al. (2006: 541) outline Glasl's model as "a detailed description of the levels of escalation". If we understand the inner logic of conflict and the situational pressure on parties, we can consciously make efforts to oppose these self-driven escalation mechanisms (Jordan, 2000).

\subsection{Conflict management strategies}

The first conflict-management strategy model was described by Blake and Mouton (1964) in the mid 1960s. They proposed five categories of conflict management styles: problemsolving, accommodation, forcing, avoidance and competing. The concept of these authors is closely in line with their widely publicized leadership style grid model. In the seventies, Thomas and Kilmann (2008) reinterpreted interpersonal conflict management strategies in the organization. To date, the best known categorization of conflict management strategies is their five-type model: competition, collaboration, accommodation, avoidance and compromise. The concept was further developed by Pruitt (1983) in the eighties. In his model, four different types of strategy were identified - based on individual or common interests. According to Pruitt, the parties to a conflict consider the self-confidence and cooperation of themselves and the other party when choosing a conflict management strategy. The parties to the negotiation choose between the following four strategies (one or more: yielding (low assertiveness / high cooperativeness), problem solving (high assertiveness / high inaction (low assertiveness / low cooperativeness) and contending (high assertiveness / low cooperativeness).

Kuhn and Poole (2000) later suggested a two-type model of conflict: distributive and integrative. According to the distributive model, only one side can be the winner; the other loses. In the integrative model, both sides can win. This model lays great emphasis on compromise. DeChurch and Marks (2001) analyzed several models of conflict-management and concluded that all strategies can be described by two dimensions: one is activity, and 
the other is collaboration. Rahim (2002) expanded this theory by claiming that one dimension is about expressing own expectations and demands, whilst the other is taking the other party's expectations into consideration. In his model, Rahim introduced five strategies: integrating, obliging, dominating, avoiding, and compromising. Other authors assert that EI (Emotional Intelligence) helps the implementation of the constructive conflict management approach. This was particularly the case with subordinates (Akerjordet and Severinsson, 2007).

\subsection{Mediation as alternative conflict resolution tool}

Mediation is a dynamic, structured, interactive process, in which a neutral third party supports the opposing parties in resolving their conflict with the help of special communication and negotiation techniques (Mareschal, 1998). The historical root of mediation dates back to the 20th century United States, when the government issued regulations in order to settle conflicts between employers and employees. As part of the legislative process, in 1947 the Taft-Hartley Act was passed leading to the establishment of the Federal Mediation and Conciliation Service (Strasser \& Randolph, 2008). Mediation comprises three distinctive parts (Riskin, 1994).

1) It is based on consensus, so that only the opposing parties can decide whether to reach an agreement or not. A mediator never forces anything on the parties.

2) It is private and confidential, so that privacy and being free from prejudice is mandatory. Nothing discussed within the framework of mediation can be given any kind of publicity.

3) Mediation is not based on rights and obligations, but rather on demands and interests. Mediation does not focus on past events and the reasons behind failures, but rather on solutions and the future.

The scientific relevance and disciplinary perspectives of mediation is wide ranging. Scholars from different fields are interested in conflict resolution and in its practical benefit. Table 1 shows the summary of disciplines that study mediation, the typical application contexts and main issues dealing based on Morasso (2011).

Table 1: Fields of mediation

\begin{tabular}{|c|c|c|}
\hline $\begin{array}{l}\text { Fields of } \\
\text { mediation }\end{array}$ & Typical application contexts & Main issues \\
\hline Juridical studies & $\begin{array}{l}\text { Family mediation, penal } \\
\text { mediation, commercial and } \\
\text { business mediation }\end{array}$ & $\begin{array}{l}\text { Alternativeness, advantages of mediation in } \\
\text { comparison to other form of dispute resolution, } \\
\text { educational background of mediators }\end{array}$ \\
\hline $\begin{array}{l}\text { (Social) } \\
\text { psychology }\end{array}$ & $\begin{array}{l}\text { Family mediation, } \\
\text { community mediation, } \\
\text { (school mediation) }\end{array}$ & Conflict, restoring relationships \\
\hline $\begin{array}{l}\text { Economics and } \\
\text { finance }\end{array}$ & $\begin{array}{lr}\text { Commercial and } & \text { business } \\
\text { mediation, } & \text { financial } \\
\text { mediation } & \end{array}$ & $\begin{array}{l}\text { Economic advantages for individuals, } \\
\text { corporations and other institutions, conflict in } \\
\text { corporations, mergers, etc., rationality of } \\
\text { economics agent in conflictual situations }\end{array}$ \\
\hline Sociology & $\begin{array}{l}\text { Community mediation, } \\
\text { social dispute mediation }\end{array}$ & Restorative justice, social effects of mediation \\
\hline
\end{tabular}


The use of commercial mediation as alternative dispute resolution tool in the Czech Republic, Hungary and Slovakia

\begin{tabular}{|l|l|l|}
\hline $\begin{array}{l}\text { Political } \\
\text { sciences }\end{array}$ & $\begin{array}{l}\text { International mediation, } \\
\text { political mediation, social } \\
\text { dispute mediation }\end{array}$ & $\begin{array}{l}\text { Conflict, negotiation, role and personality of third } \\
\text { parties in international processes, power issues }\end{array}$ \\
\hline Argumentation & $\begin{array}{l}\text { Family mediation (divorce } \\
\text { mediation), community } \\
\text { mediation, } \\
\text { mediation. }\end{array}$ & $\begin{array}{l}\text { Quality of argumentation and quality of } \\
\text { mediation. Mediator's communicative } \\
\text { instrumentation for fulfilling their task }\end{array}$ \\
\hline
\end{tabular}

Source: the authors' own research based on Morasso (2011)

\subsection{Commercial/business mediation}

Mediation offers parties a chance to gain deeper understanding of their dispute and limit the cost of extended legal action. Today wide spectrum of organizations need mediation services. Empirical research on commercial mediation is still rare. Filler (2012) show the diversity of styles, approaches and forms of mediation developed in Europe. The goals of commercial mediation are clear-cut: minimizing costs and losses in an relevant way. A mediator concentrates on resolving the conflicts between economic parties and on working towards the development of a mutually acceptable resolution. Commercial mediation can be effectively used in a variety of ways: to solve legal and compensation disputes, to settle agreements between creditors and debtors in liquidation procedures, resolving disputes between employers and employees, in concluding disputes related to task management, human resource problems, workplace bullying and abuse, as well as ending disputes related to copyright and intellectual property.

\section{Country-specific issues of conflict management and commercial mediation}

\subsection{Commercial conflict management in the Czech Republic}

Mediation found its way into the Czech Republic shortly after the collapse of socialism in 1989. It was introduced by American professionals from the non-governmental organization Partners for Democratic Change. Local professionals realized the benefits of mediation and established the Centre of Agreement and Partners in 1991 (Holá, 2011). From 1993 onwards, mediation was introduced for municipalities in the form of Conciliation Boards to help in solving conflicts within local communities. The members of the Board worked on a voluntary basis, free of charge in their free time. The first Conciliation Board was established in Prague and today it is still present in major cities such as Ostrava, Pardubice, and Vsetín (Holá, 2015). The Association of Mediators in the Czech Republic was established in 2000 and the Chamber of Mediators and Facilitators in 2012.

Mediators have been very active in promoting mediation to both law professionals and the general public by publicizing conferences, lectures, speeches, articles and media interviews. They do it both individually and in cooperation within several professional organizations. Conferences, training and other forms of education are also arranged by these organizations and universities for professional mediators to help them in their growth. 
There are several non-governmental organizations established by mediators such as Association of Mediators of the Czech Republic in 2000 and Chamber of Mediators and Facilitators in the Czech Republic in 2014. Competition "The Mediator of the Year" started in 2019 by Centre for Dispute Settlement (Centrum pro řešení sporů s. r. o) and media and educational group EPRAVO.cz. under the auspices of the Minister of Justice of the Czech Republic. There are categories: family mediator, business mediator, pro bono mediator, legal person supporting mediation, counsel mediator, legal office supporting mediation and mediator between victims and offenders. Mediation is also an academic subject within the curriculum in law faculties, e.g. Law Faculty of Charles University in Prague started teaching mediation in 2014.

The Probation and Mediation Act. No. 257/2000 Coll. was passed to serve the needs of the criminal justice. The Mediation Act No. 202/2012 Coll. was passed in 2012. It regulates all aspects of civil mediation - the process of mediation, the responsibilities of mediators, confidentiality and oversight, the process of becoming a registered mediator, the examination for registered mediators and the breach of responsibilities too. There are currently 240 registered mediators according to the official list published by the Ministry of Justice of the Czech Republic and dozens more who are not registered. Some are working on an individual basis, others are located in mediation centers. Some mediators practice mediation in all areas of law, whilst others specialize in certain areas - namely business law, family law and trade union settings. To become a registered mediator, one has to pass written and oral exams administered by the state authority.

The Ministry of Industry and Trade is a very active promoter of mediation. It organized the Out-of-Court consumer mediation and arbitration pilot project for two consecutive years - 2008 and 2009. Its main goals were to help resolving disputes, minimize the time spent on consumer confrontation, maximize mutual agreements, motivate voluntarism, strive for impartiality during proceedings, ease accessibility and lower financial demands on the contending parties involved. Completion of conflict resolution was set to 60 days (ideal time) or 90 days (maximum time). Mediation was free of charge for participants (entrepreneurs and consumers); mediators and attorneys were paid by the Ministry. The Ministry of Justice, the Ministry of Finance, the Chamber of Commerce of the Czech Republic, the Court of Arbitration of the Chamber of Commerce and Agriculture of the Czech Republic, the Association of Mediators and Consumer Organizations all cooperated in these projects. In total, 22 contact places were included in the project, whilst 28 mediators and 59 arbitrators, who met the qualification criteria, were listed on the online pages of the Ministry of Industry and Trade.

From 1 April to 31 December 2008, there were 1077 requests for dispute resolutions from the three largest cities of the country - Prague, Ostrava and Brno. Some 862 cases were successfully concluded. Of these, 320 cases were successfully resolved simply by providing information and recommendations on the spot. In 49 cases mediation, and, in one case only, arbitration was carried out. In the remaining 492 cases one of the parties did not agree with the proposal for an out-of-court solution or did not react within the designated period. Typical subjects of dispute were complaints about various types of product such as 
laptops, furniture, cameras etc. This project shows that if the government promotes mediation, positive results will appear.

\subsection{Commercial conflict management in the Slovak Republic}

Mediation in Slovakia is described and regulated in Act No. 420/2004 Coll. on mediation and amending certain laws. Based on Article 1 (2) of this law, mediation is an extrajudicial action in which the parties settle a dispute arising from or concerning their contract or other legal relationship through a mediator. Referring to Article 1 (3) of this Act, a mediator may be any natural person registered in the Register of Mediators at which the persons involved in mediation agree, and the mediator concludes mediation agreements with the persons involved in mediation in accordance with Article 1 (14) of the Slovak Mediation Act 2004. In 2014 a team of experienced authors processed a Commentary on the Act No. 420/2004 Coll. on Mediation. The commentary (Budjač et al., 2014) addresses the mediation process in detail, the legal nature of mediation agreement, the eligibility of mediation and professional mediator training, the control of mediation activity and the specifics of mediation in consumer disputes.

As part of the long-term programs of the civic association PDCS (Partners for Democratic Change in Slovakia), Conciliation Boards were established in Slovakia in 2015. In addition to the center established in Bratislava, a mediation center in Banská Bystrica and the Conciliation Board in Prešov and Levice were also established. The Conciliation Boards in Nové Zámky, Rimavská Sobota and Kežmarok had been PDCS branches for four years (PDCS, 2019). These Conciliation Boards are voluntary associations of people from different profession fields, whose task is to help citizens or groups resolve their disputes and conflicts through mediation.

The scientific literature addressing the issue of mediation also exists in Slovakia. The practical legal guide "Mediation" (Swanová et al., 2016) focuses in particular on the practical aspects of mediation and changes to the Mediation Act implemented in 2016. Beyond the legal analysis and interpretation, it provides a comprehensive view of alternative conflict resolution through the mediation method. The brochure, "Possibilities of Mediation in Self-Government or from a Mayor to Mediator" (Kutlík, 2008) introduced the basic mediation skills to municipalities, focusing on avoiding disputes and improving human relationships.

The Office of the Association of Towns and Communities of Slovakia distributed this brochure to all towns and villages. The aim was to teach the representatives of municipalities - mayors, councilors and employees -how to resolve disputes through mediation. At the same time, they can also learn how to avoid conflict arising in villages and towns. The publications "Mediation in Healthcare" (Kutlík, 2017) and "School and Peer Mediation" (Bieleszová, 2017) were prepared for specific groups, addressing the patient - healthcare worker, healthcare worker- healthcare worker and pedagogical and professional school staff-pupil-student-parent relationships. The absence of interaction or different attitudes to cultural or religious values may disturbed interpersonal relationships at the workplace and can generate a wide range of conflicts. Publications bring alternative 
ways of resolving a particular problem through implementing the mediation process. "Applying Mediation in Civil Law" (Mrázek, 2012) is a publication designed especially for university students.

There is a low intensity of mediation research in Slovakia, and so every survey initiative is valuable. Pružinská (2007) asked mediators registered on the List of Mediators published on the website of the Ministry of Justice of the Slovak Republic to complete a questionnaire. The total number of mediators at that time was 145 , with $5 \%$ of the sample examined consisting of lawyers and $45 \%$ of non-lawyers. During the 2.5 years following the implementation of the Act on Mediation, the number of mediated disputes increased by 128 for the sample of mediators. These mediators helped the parties to reach an agreement in half of the cases. The mediation agreement ended civil, family, commercial and labor disputes. Recent research by the Theological Faculty of the University of Prešov and Mediation Centre (2016) focused on how informed the respondents were about mediation as a technique to resolve conflicts and disputes. There were 61 respondents involved in the survey and their ages are shown on a scale from 20 to 69 . Most of them, $80 \%$ of the respondents, had experienced civil litigation in the past; whereas a minority specified family, commercial and labor disputes. Whilst $69 \%$ know what the term mediation means, half of the respondents are aware of where to contact a mediator if needed. The respondents reported the benefits of mediation as being 'financially advantageous', 'faster and easier'.

Many young people consider mediation as an interesting area for their own professional activity in Slovakia, and we have statements and interviews of mediators on $\mathrm{TV}$, radio and on the Internet. Offices and their staff offer expanding services in family, neighborhood litigation, labor litigation, property, civil and commercial litigation. Mediators are available, and, as they operate in regional cities, it is quite easy to contact and meet them. The initial consultation is usually free of charge and is an initial assessment of the specific case - of the dispute. Accepting the case, its comprehensive study and solution is charged. The mediator is either called by both sides of the dispute at the same time or is called by one of the parties and he contacts the other after that. The prerequisite is the consent of all parties to the dispute to start the mediation process. The usual outcome of this is a mediation agreement, which contains the consensus of all those involved. Mediation is not recommended in cases involving fundamental human rights and constitutional rights. The average mediation lasts from one day, but, depending on the complexity of the dispute and the number of parties involved, may extend to several weeks.

\subsection{Commercial conflict management in Hungary}

In Hungary, the National Mediation Association was established in 2000. The association is an NGO, and, according to its statutes, its aim is to popularize mediation as a means of conflict-management in Hungary. A further aim is to organize the work of professionals in the field of mediation education and practice. The main activity of the association is to support, organize, and coordinate the work of mediators, furthermore to represent and protect the interest of these professionals and use these activities to promote, introduce, teach and create research related to processes of mediation. The association 
constantly seeks to adapt international research findings, organize conferences, training and cooperate with national and international organizations .

Mediation activity has been under the supervision of national legislation since 2002. The 2002 LV. Mediation Act defines the term mediation, and, according to the Act, mediation is a unique conflict-management, dispute settling procedure that aims to settle a dispute between the opposing parties by involving a neutral third party (mediator) in order to solve the disputes with a written consensus. The role of the mediator is to be unbiased and contribute to a dispute settlement agreement to the best of their knowledge (Lux, 2014).

A government decree (Act No. 185/2009. Coll.) amended the 2002 Mediation Act (IX. 10.), which regulates how one can use an official mediator. The regulation defines the conditions under which one can become an official mediator, and how the person can be registered as such.

The training requirements and participation therein are determined in the 63(XII. 17.)IRM regulation. The Bill regulates in detail the requirements to be fulfilled to become a mediator and how to acquire the necessary credit points. According to this, mediators need to complete a 60 -hour theoretical training program and, during their practical training, they also need to present at least one mediation case study which was completed.

The 2006 CXXIII. Bill of Mediation Practice in Criminal Cases, which became law on 1 January 2007, defines how and when to use mediation in criminal cases. This Act makes reparations possible as a component of a mediation agreement.

The 2016 CXXX. Code of Civil Procedure, effective on 1 January 2018, enables the use of mediation in corporate disputes. After the initiation of the lawsuit, it is possible to have a mediator involved, for example, when a company general meeting wants to exclude a member, or when conflicts arise between family members in a family business, or between employer and employees in an organization.

Research in the field of mediation gathered momentum after Hungary's democratic transformation. The National Scientific Bibliography Database, also known as MTMT in Hungarian, contains 318 articles with the keyword "mediation", 479 publications with the word "mediator", and 63 use the term "alternative dispute settlement". The first paper in this research field dates back to 1973, but the next did not appear until 1989. The topic became more popular after the democratic transformation, although it is still lacking research material.

\subsection{Country specific frameworks of commercial conflict management}

In countries in the developed world, such as the United States, the United Kingdom, or even Belgium, various forms of mediation have been used in labor disputes for nearly 70 years (Potocnik et al, 2019). Today, four different models have emerged in the European Union. One model is the completely voluntary model. The other is a voluntary model that is helped with some financial support, while for the third model, it is initially mandatory to 
use a mediator. And finally, there is the model where mediation is mandatory before any legal act (Elgoibar et al., 2019). In addition to the relatively weak and declining trade union activity (Morley et al, 2015; Cranet, 2017), the first and second models are the now common in Eastern Europe including the analysed three countries.

Table 2: The national approaches to mediation in Czech Republic, Hungary and Slovakia

\begin{tabular}{|c|c|c|c|}
\hline $\begin{array}{l}\text { Characteristics of } \\
\text { mediation }\end{array}$ & Czech Republic & Hungary & Slovakia \\
\hline $\begin{array}{l}\text { What } \\
\text { disagreements } \\
\text { (formal vs. less) } \\
\text { does mediation } \\
\text { cover? Formal } \\
\text { disagreements } \\
\text { covered only vs. } \\
\text { Less formal } \\
\text { disagreements } \\
\text { covered. }\end{array}$ & $\begin{array}{l}\text { - Disputes that cover all legal } \\
\text { issues except criminal law, } \\
\text { which is regulated and } \\
\text { mediated separately. }\end{array}$ & $\begin{array}{l}\text { - Family, divorce, } \\
\text { relationship, } \\
\text { commercial/business, } \\
\text { organizational, other } \\
\text { dispute resolution } \\
\text { (educational, labor, } \\
\text { health, office, minority } \\
\text { etc.) } \\
\text { - Both formal and less } \\
\text { formal disagreements } \\
\text { covered. }\end{array}$ & $\begin{array}{l}\text { - Family ligitation, } \\
\text { neighbourhood } \\
\text { litigation, labor } \\
\text { litigation, property, civil } \\
\text { and commercial } \\
\text { litigation, } \\
\text { - Mediation is not } \\
\text { recommended in cases } \\
\text { involving fundamental } \\
\text { human rights and } \\
\text { constitutional rights }\end{array}$ \\
\hline $\begin{array}{l}\text { Mediation is } \\
\text { general vs. } \\
\text { contextually } \\
\text { specific (by } \\
\text { industry or } \\
\text { institution) (as } \\
\text { may be the case } \\
\text { in Slovakia) }\end{array}$ & $\begin{array}{l}\text { - Contextually specific by } \\
\text { several areas, }\end{array}$ & $\begin{array}{l}\text { - } \quad \text { Contextually specific } \\
\text { by several areas }\end{array}$ & $\begin{array}{lll}\text { Contextually } & \text { specific by } \\
\text { several areas } & & \end{array}$ \\
\hline $\begin{array}{lr}\text { Mediation } & \text { is } \\
\text { nationally } & \\
\text { standardized } & \text { vs. } \\
\text { regionalized } & \end{array}$ & $\begin{array}{l}\text { - } \text { Regulated by Act } \\
\text { No.202/2012 Coll. } \\
\text { Mediation Code }\end{array}$ & $\begin{array}{l}\text { Regulation: 2002 } \\
\text { LV. Mediation Act; } \\
\text { Act No. 185/2009. } \\
\text { Coll.; 63(XII. 17.) } \\
\text { IRM; 2006 CXXIII. } \\
\text { Bill of Mediation } \\
\text { Practice in Criminal } \\
\text { Cases; 2016 } \\
\text { CXXX. Code of } \\
\text { Civil Procedure } \\
\text { Mediation Centers } \\
\text { are established in } \\
\text { each county by } \\
\text { national mediation } \\
\text { office } \\
\text { (https://mediatoriro } \\
\text { da.hu/) }\end{array}$ & $\begin{array}{l}\text { - } \text { Regulated in Act No. } \\
420 / 2004 \text { Coll. on } \\
\text { mediation and } \\
\text { amending certain } \\
\text { laws, } \\
\text { - Mediation Centers are } \\
\text { established in district } \\
\text { towns on regional } \\
\text { level }\end{array}$ \\
\hline $\begin{array}{l}\text { Mediation is by } \\
\text { government } \\
\text { financed vs. paid } \\
\text { for by fees from } \\
\text { the parties. }\end{array}$ & $\begin{array}{l}\text { - If ordered by the court, it } \\
\text { is paid by the state. } \\
\text { If not ordered by the } \\
\text { court, then the parties } \\
\text { hiring a mediator pay } \\
\text { mediation fee equally to } \\
\text { the mediator (unless } \\
\text { agreed otherwise). }\end{array}$ & $\begin{array}{l}\text { - Some providers offer } \\
\text { a free mediation } \\
\text { service, but there is } \\
\text { none from the state. } \\
\text { Otherwise, most of } \\
\text { the mediation service } \\
\text { is paid }\end{array}$ & $\begin{array}{l}\text { - } \text { The initial } \\
\text { consultation is } \\
\text { usually free of } \\
\text { charge, } \\
\text { Accepting the case, } \\
\text { its comprehensive } \\
\text { study and solution is } \\
\text { charged, }\end{array}$ \\
\hline
\end{tabular}




\begin{tabular}{|c|c|c|c|}
\hline & & & $\begin{array}{l}\text { - The mediator is } \\
\text { entitled to be paid for } \\
\text { the performance of } \\
\text { mediation }\end{array}$ \\
\hline $\begin{array}{l}\text { Mediators } \\
\text { regulated and } \\
\text { registered, with a } \\
\text { certification exam } \\
\text { required vs. } \\
\text { Volunteers? }\end{array}$ & $\begin{array}{l}\text { - The mediator can be any } \\
\text { natural person registered } \\
\text { in the Register of } \\
\text { Registered Mediators, } \\
\text { who: } \\
\text { a) is fully competent to } \\
\text { perform legal acts, } \\
\text { b) has no criminal record, } \\
\text { c) obtained a master's } \\
\text { degree from } \\
\text { university, } \\
\text { d) successfully passed } \\
\text { state mediation } \\
\text { exam, } \\
\text { e) was not barred from } \\
\text { the Register of } \\
\text { Registered } \\
\text { Mediators in past } 5 \\
\text { years according to } \\
\text { Act No.202/2012 } \\
\text { Coll. } \S 22 \text {, } \\
\text { f) paid administrative fee } \\
\text { to Ministry of } \\
\text { Justice. }\end{array}$ & $\begin{array}{l}\text { Based on Act LV of } \\
2002 \text { the Ministry of } \\
\text { Justice shall maintain } \\
\text { a register of } \\
\text { mediators, also } \\
\text { containing the names } \\
\text { of legal persons and } \\
\text { unincorporated } \\
\text { business associations } \\
\text { employing mediators. } \\
\text { The training } \\
\text { requirements and } \\
\text { participation therein } \\
\text { are determined in the } \\
\text { 63(XII. 17.) IRM } \\
\text { regulation. Mediators } \\
\text { need to complete a } \\
\text { 60-hour theoretical } \\
\text { training program and, } \\
\text { during their practical } \\
\text { training, they also } \\
\text { need to present at } \\
\text { least one mediation } \\
\text { case study which was } \\
\text { completed. }\end{array}$ & $\begin{array}{l}\text { - The mediator can be } \\
\text { any natural person } \\
\text { registered in the } \\
\text { Register of } \\
\text { Mediators, who: } \\
\text { g) is fully competent } \\
\text { to perform legal } \\
\text { acts, } \\
\text { h) obtained a second } \\
\text { university } \\
\text { degree, } \\
\text { i) is innocent, } \\
\text { j) has a certificate of } \\
\text { successful } \\
\text { completion of } \\
\text { the mediator's } \\
\text { professional } \\
\text { training and } \\
\text { completion of } \\
\text { the mediator's } \\
\text { professional } \\
\text { examination }\end{array}$ \\
\hline
\end{tabular}

Source: the authors' own research

\section{Methodology}

\subsection{Questionnaire and hypotheses}

Commercial conflict management research was conducted in three countries: the Czech Republic, Hungary and Slovakia in 2018. The method of sample collection for the given survey was as follows. The respondents completed the questionnaire voluntarily; the questionnaire typically consisted of closed questions, generally based on nominal variables' the questions could be divided into several groups. The structure of the questionnaire is summarized in the following table 3.

Table 3: Structure of the questionnaire

\begin{tabular}{|c|c|c|}
\hline Organizational Characteristics & Organizational Conflict & Mediation \\
\hline $\begin{array}{l}\text { - Company size } \\
\text { - Main activities (sector) of the } \\
\text { organization } \\
\text { - Company ownership } \\
\text { - Characteristics of employees }\end{array}$ & $\begin{array}{l}\text { - Internal processes for } \\
\text { managing conflicts } \\
\text { - Types of conflict } \\
\text { - Conflict-management } \\
\text { methods }\end{array}$ & $\begin{array}{l}\text { - Use of mediation } \\
\text { - Effectiveness of mediation } \\
\text { - Willingness to introduce } \\
\text { mediation }\end{array}$ \\
\hline
\end{tabular}

Source: the authors' own research 
Among other things, the authors analysed the validity of the following hypotheses:

Hypothesis 1: The organizations in the study differ from country to country in the use and success of mediation practices.

Hypothesis 2: The nature of conflict and the success of mediation are influenced by the size of the organization.

\subsection{Sample characteristics}

Some 297 companies completed the questionnaire: 101 from the Czech Republic, 108 from Hungary and 88 from Slovakia. Based on organizational size, $42 \%$ of the companies surveyed had fewer than 51 employees; $35 \%$ had more than 51 but fewer than 500; some $20 \%$ had more. In terms of country, $26 \%$ of the Czech companies employed fewer than 51 people, whilst 36\% employed between 100 and 500 .

The largest proportion of Hungarian companies (46\%) employ fewer than 51 people, and in the Slovak sample 53\% were also small companies (with 50 or fewer employees).In terms of activity, the companies were most active in the following sectors: $13 \%$ in sales and trading, $13 \%$ in manufacturing, $12 \%$ in services, $12 \%$ in electrical energy, and 6\% in transport and logistics.

According to a country-by-country analysis, Czech companies accounted for $30 \%$ of the manufacturing and $18 \%$ of the energy industry. Hungarian companies provided services in $20 \%$ and sales and trading in $10 \%$. The Slovak sample was also dominated by organizations in the sales and trading sector (13\%), and by manufacturing companies $(13 \%)$.

In terms of ownership, $52 \%$ of Czech companies were Czech-owned, $74 \%$ of Hungarian companies were Hungarian-owned, and $72 \%$ of Slovakian companies were Slovak-owned. In this respect, the firms operating in the three countries were significantly different from each other (Chi-square test: 13.146 df: 2, sign: 001 $\mathrm{p}<.05)$.In the case of Czech companies, foreign owners were mostly American, French and German (17\% -17\% -17\%). The Hungarian companies had American (35\%) and Slovakian organizations, German and American owners (36\% - 12\%). Some 35\% of the companies surveyed had foreign workers. This is typical of $60 \%$ of Czech organizations, $24 \%$ of Hungarians and $22 \%$ of Slovak companies employing nondomestic workers. Organizations differed significantly across countries on this issue (Chi-square: 40.493 df: 2, sign: 000 p<.05).

Looking at the proportions of women and men, in $44 \%$ of companies, the proportions are nearly equal - over $60 \%$ were men in $24 \%$ of organizations, and far more women, up to $60 \%$, were employed by $13 \%$ companies. Czech companies have 
the highest proportion of women to men (38\%), similarly to Hungarian organizations (51\%) and Slovak companies (44\%).

\subsection{Analysis}

During the research, the responding organizations were asked to conduct a regular employee engagement survey of the organizations. Some $36 \%$ answered yes and $64 \%$ refused. Examined by country, the survey was conducted on a regular basis, while $64 \%$ of Czech organizations, $29 \%$ of Hungarian organizations and $14 \%$ of Slovak companies carried out such surveys on a regular basis. The Chi-square study shows a significant difference by country: Chi-square: $55.592 \mathrm{df:} 2$, sign: $000 \mathrm{p}<.05$. The study also found that $65 \%$ of companies with foreign employees had regular employee satisfaction surveys, compared with only $21 \%$ of those who did not. The Chi-square test confirmed the significant difference (Chi-square: 54.784 df: 2, Significant: 000 $\mathrm{p}<.05$ ). Some $37 \%$ of organizations develop internal processes for managing conflict, whilst $67 \%$ do not. About $30 \%$ of Czech companies do this, but $39 \%$ of Hungarians and $43 \%$ of Slovaks. The research also asked what types of conflict can be expected within the organizations. Table 4 summarizes the frequency of possible conflict types:

Table 4: Types of conflict

\begin{tabular}{|c|l|c|}
\hline No & \multicolumn{1}{|c|}{ Types of conflict } & $\%$ \\
\hline 1 & Between individuals & 86.3 \\
\hline 2 & Between company and employees & 25.4 \\
\hline 3 & Between teams & 16.6 \\
\hline 4 & Between Company and B2B Clients & 16.1 \\
\hline 5 & Between company and suppliers & 9.7 \\
\hline 6 & Between company and state & 3.7 \\
\hline 7 & Between a company and a foreign parent company & 1.7 \\
\hline \multicolumn{2}{|c|}{ Source: the authors' own research }
\end{tabular}

The data in Table 5 clearly show that conflicts between individuals and the company and employees are the most frequent, while problems between the company and the parent company are least frequently reported. These types of conflict have also been examined on a country-by-country basis. The results are shown in Table 5 .

Table 5: Types of conflicts by countries (\%)

\begin{tabular}{|l|c|c|c|}
\hline \multicolumn{1}{|c|}{ Types of conflict } & Czech Republic & Hungary & Slovakia \\
\hline Between individuals & 85.1 & 85.2 & 90.9 \\
\hline Between teams & 14 & 25.9 & 8 \\
\hline Between company and employees & 31 & 20.4 & 26.1 \\
\hline Between company and suppliers & 13 & 9.3 & 6.8 \\
\hline Between Company and B2B Clients & 25.7 & 7.4 & 15.9 \\
\hline Between a company and a foreign parent company & 3 & 0.9 & 1.1 \\
\hline Between company and state & 5 & 3.7 & 2.3 \\
\hline
\end{tabular}

Source: the authors' own research 
Based on the data in Table 4, the most frequent conflicts in the Czech Republic are between individuals, between the company and employees, and between the company and B2B clients. In the case of the Czech Republic, an intuitive assumption was supported by the cross-tabulation analyzes: the more employees a company has, the more frequently we find conflict between individuals. For example, 80 percent of those companies which employ 101-500 people and 100 percent of those companies which employ between 1001-5000 face this problem. Conflicts among companies and employees most commonly occur in the case of large companies; in two-thirds of such firms (employing more than 5,000 people), while in those with fewer than 51 employees this problem emerges only in one out of ten companies. Examining the ownership structure in the Czech Republic, the frequency of conflicts between companies and individuals is almost the same, about $80 \%$ for both domestic- and foreign-owned companies. At the same time, in case of domestic-owned companies, there are fewer conflicts between the company and its employees (26.9\%) compared to the foreign owned counterparts and its employees $(35.4 \%)$. The appearance of foreign workers in a given workplace does not really affect the proportions of individual conflicts (if they are present, conflict rates are $86.4 \%$ and if they are not, $87.5 \%$ ).

In Hungarian organizations, most often found problems occur between individuals and teams and between the company and the employees. Based on the size of the organization, it can be said that individual conflicts are more common (frequency above 90\%) in larger companies and among those which employ less than 50 employees (85.7\%). One in two employers in the 51-100 group has had such an issue, while for those firms with over 5,000 employees this proportion is only $20 \%$. Based on the ownership, there is no significant difference in the incidence of conflicts between individuals. Individual conflicts occur with a frequency of $85.9 \%$ in Hungarian-owned companies and $88.9 \%$ in their foreign-owned counterparts. Team conflicts occur in $23.1 \%$ of domestic companies and in $37 \%$ of foreign companies.

Conflicts in Slovak companies are similar to those in Czech organizations. In the case of Slovak companies, individual conflict is more common (91.5\%) in smaller firms (fewer than 50 employees) than in larger ones $(75 \%$ for companies employing 1001-5000 people). Some 50\% of companies which have more than 1000 employees face conflicts arising between the employees and the firm itself, which is a much higher proportion than what we can see in the case of small companies $(10.6 \%)$. Conflicts between individuals occur more often in Slovak-owned organizations $(92.1 \%)$ than in their foreign-owned counterparts $(88 \%)$. Conflicts between the company and the employers, however, are more frequent among foreign-owned firms (17.5\% for Slovaks and 48\% for foreigners). Companies spend at least $10 \%$ of their working time dealing with internal conflicts, while $2.1 \%$ of organizations spend up to $30-40 \%$. Fully $86 \%$ of Czech companies, $73 \%$ of Hungarian companies and $81 \%$ of Slovak companies spend at least $10 \%$ of their working hours responding to internal conflicts. Some $79 \%$ of organizations focus on managing external conflicts for at least 
$10 \%$ of their working time. $85 \%$ of Czech participants, $73 \%$ of Hungarian and $74 \%$ of Slovak respondents do so. Some $9 \%$ of companies use mediation as a method of resolving conflicts. There was no difference in the three countries' organizations in this respect: Pearson's Chi test:, 847 df: 2, sign: $6.555, \mathrm{p}>.05$. 7\% of Czech organizations, $11 \%$ of Hungarians and $10 \%$ of Slovaks use this tool. $88.7 \%$ of the organizations have not used mediation in the last two years, but $4 \%$ of the companies have done so at least once. The success rates of commercial mediation are shown in Table 6:

Table 6: Success rate (\%) of mediation

\begin{tabular}{|l|c|}
\hline \multicolumn{1}{|c|}{ Successfulness of mediation } & $\%$ \\
\hline Thanks to mediation, the disputes were settled and the parties reached a full agreement & 72.4 \\
\hline Thanks to mediation, the disputes were settled and the parties partially reached an agreement. & 17.2 \\
\hline Disputes were not resolved, but no court action was taken. & 6.9 \\
\hline Disputes were not resolved and court proceedings were initiated. & 3.4 \\
\hline
\end{tabular}

Source: the authors' own research

On the basis of the frequency of success, it can be seen that most parties reached a complete agreement in almost all cases. When examining success, no significant difference could be identified between countries: Pearson's Chi-square: 6.059 df: 6sig.:417 p>.05.

Some $85.7 \%$ of Czech companies settled disputes successfully through mediation; $14.3 \%$ did not settle the issues, however, no court proceedings were initiated between the parties after the failure of mediation. In Hungary, $76.9 \%$ solved the issue completely through mediation, $15.4 \%$ partially resolved it via mediation, and $7.7 \%$ went on to court. In Slovakia, $72.4 \%$ resolved the issue entirely through mediation, $17.2 \%$ achieved only partial results through mediation, $6.9 \%$ did not resolve but did not go to court as well, and only $3.4 \%$ went on to court. In the Czech Republic, $7.4 \%$ of the organizations surveyed will use mediation as a tool for conflict management, in Hungary this statistic was $11.1 \%$ while in Slovakia it was $10.2 \%$. Finally, $73 \%$ of companies stated that they do not want to introduce mediation as a practice at the company, but $20 \%$ will consider it as a conflict-management tool, $1 \%$ will use it as a labor law instrument, and 5\% reported they would use it as an internal mediator. The characteristics and composition of the organizations did not show significant differences. The organizations did not differ from country to country. In case of conflict, $2.1 \%$ of Czech firms involve an internal mediator to resolve the issue; this is true for $7.2 \%$ of Hungarian firms while $3.1 \%$ of them will use mediation as a labor law tool. In Slovakia, 5\% of respondents think that they will have an internal mediator and $2.1 \%$ will use it as a labor law tool.

The authors also examined mediation in organizations based on company size, as the second hypothesis is related to the number of employees. The researchers formed three categories based on company size. 
The first group consisted of companies with fewer than 50 employees, the second with more than 50 but fewer than 500 and the third with 500 employees or more. There were 122 companies in the first category, 105 in the second and 67 in the third. 3 respondent companies did not participate in the investigation since they did not provide information on the size of their company. Cross-table analysis was used to examine the extent to which each type of conflict is affected by the size of the organization. The typologies of conflict as previously presented were: between individuals, teams, company and employees, company and suppliers, company and B2B clients, company and foreign parent company, company and state. Table 7 shows the types where significant differences could be identified based on different company sizes:

Table 7: Relationship between Conflict Type and Company Size $(P=0.05)$

\begin{tabular}{|c|c|c|c|c|c|}
\hline \multirow[b]{2}{*}{ Number of employees } & \multicolumn{2}{|c|}{ Between teams } & \multicolumn{3}{|c|}{ Chi-square test } \\
\hline & No & Yes & Value & $\mathrm{df}$ & Sign. \\
\hline Fewer than 50 & $91.0 \%$ & $9.0 \%$ & \multirow{4}{*}{9.04} & \multirow{4}{*}{2} & \multirow{4}{*}{0.011} \\
\hline Between 50-500 & $79.0 \%$ & $21.0 \%$ & & & \\
\hline 500 and above & $76.1 \%$ & $23.9 \%$ & & & \\
\hline \multirow[t]{3}{*}{ Total } & $83.3 \%$ & $16.7 \%$ & & & \\
\hline & Between co & d employees & \multicolumn{3}{|c|}{ Chi-square test } \\
\hline & No & Yes & Value & $\mathrm{df}$ & Sign. \\
\hline Fewer than 50 & $88.5 \%$ & $11.5 \%$ & \multirow{4}{*}{24.876} & \multirow{4}{*}{2} & \multirow{4}{*}{0} \\
\hline Between 50-500 & $70.5 \%$ & $29.5 \%$ & & & \\
\hline 500 and above & $56.7 \%$ & $43.3 \%$ & & & \\
\hline Total & $74.8 \%$ & $25.2 \%$ & & & \\
\hline
\end{tabular}

Source: the authors' own research

The data in the table suggests that, as the size of the company increases, the frequency of conflicts between teams and between the company and employees also increases. This is logical, since the more people work within an organization, the more likely it is that conflict situations will occur. Although there was no significant difference between individuals in the sample, it was supported by the fact that the frequency of employee-to-employee problems was more common in a larger organization than in a smaller one. Mediation has been used by at least $12 \%$ of firms with fewer than 50 employees, $14 \%$ of those with more than 49 employees but fewer than 500 and $8 \%$ of larger firms over the past two years. In terms of success, Table 8 summarizes the results:

Table 8: Relationship between Conflict Type and Company Sizes

\begin{tabular}{|lc|c|c|c|}
\hline & Company size & Fewer than & Between & 500 \\
Conflict type & & 50 & 5 and & and \\
\hline
\end{tabular}




\begin{tabular}{|c|c|c|c|}
\hline & & 500 & beyond \\
\hline $\begin{array}{l}\text { Thanks to mediation, the disputes were settled, and the parties } \\
\text { reached a full agreement }\end{array}$ & $75.0 \%$ & $66.7 \%$ & $80.0 \%$ \\
\hline $\begin{array}{l}\text { Thanks to mediation, the disputes were resolved, and the parties } \\
\text { partially reached an agreement. }\end{array}$ & $8.3 \%$ & $25.0 \%$ & $20.0 \%$ \\
\hline Disputes were not resolved, but no legal action was taken. & $8.3 \%$ & $8.3 \%$ & $0.0 \%$ \\
\hline Disputes were not resolved, and legal actions were taken. & $8.3 \%$ & $0.0 \%$ & $0.0 \%$ \\
\hline
\end{tabular}

Source: the authors' own research

The data in the table show that mediation was the most successful in large organizations, although the number of cases in which small entities eventually did go to court was relatively small.

\section{Conclusions}

In our research, we aimed to examine how organizations practice mediation and commercial conflict management in three Central European countries, namely in the Czech Republic, Slovakia and Hungary. To do this, we looked at the concept of organizational conflict, its escalation and the set of conflict-management strategies. After the introduction of the theory, we analyzed the practice of organizational mediation in all of the three countries. Mediation was introduced in all of them after the change of the political system in the 1990s. The laws regulating it were passed by legislativ bodies a few years later, at the beginning of the new millennium. Since the system of mediation and regulations differs (See Table 2) in the three countries, we assumed that mediation practice and success would differ too. Our second hypothesis is that the nature of conflict and the success of meditation are influenced by the size of the organization. Our questionnaire-based survey, including three topics (organizational characteristics, organizational conflict characteristics, use of mediation), was carried out at 297 companies (101 Czech, 108 Hungarian and 88 Slovak). Based on our results, both of our hypotheses are rejected. Surveys in the given companies have shown that many forms of conflict can be identified - between individuals, teams, between companies and their employees, and between companies and their external parties (business partners and state). Results of the survey confirmed firms still use mediation as a conflict-management tool in a relatively narrow range. The authors therefore reject Hypothesis 1. Based on this, it can be stated that the companies examined in the three countries showed no difference in respect of mediation. Further research will show what drives management in companies not to use a tool, which has proved itself successful.

Concerning the second hypothesis, there could be seen differences in terms of mediation issue in organizations of different sizes, nevertheless it is not possible to state unequivocally that they behave differently. The authors also reject this hypothesis. Surveys at the given companies have shown that many forms of conflict can be identified, yet firms still use mediation as a tool for conflict-management to a relatively 
limited extent. Slightly different types of conflicts dominate in the countries we examined. In the Czech Republic and Slovakia, conflicts between individuals, conflicts between companies and their employees, conflicts between companies and B2B clients can be identified most commonly. Meanwhile, in case of Hungarian organizations there is more often a problem between individuals, teams and in regard of companies and their employees. Although mediation can be considered as a very successful tool, organizations rarely apply it. In this respect, the authors reject their first hypothesis. Based on this, it can be stated that the companies examined in the three countries showed no difference in respect of mediation.

Overall, we can say that the practice of mediation has been on in the three analyzed Central European countries; however, there are still huge untapped opportunities in the field. The widest possible use of mediation can advance an increase in organizational satisfaction (Bingham, 2004; Seargeant, 2005), a strengthening of organizational trust (BIS, 2011) and an improvement in workplace relationships (Saundry et al., 2013). Mediation has an impact on improving the conflict management skills of leaders (Bingham, 2004) and on the development of problemsolving skills too (Kressel, 2006). Ultimately, mediation also has an impact on the entire organizational culture. The introduction of organizational mediation increases employee trust in the organization itself, in the field of interpersonal relations (OlsonBuchanan \& Boswell, 2008) and, last but not least, it results in a reduction in the number of conflicts (Mareschal, 2005). The aforementioned together increase the efficiency of organizations, the functioning of organizations and thus the net output performance.

\section{References}

Akerjordet, K. \& Severinsson, E. (2007). Emotional intelligence: A review of the literature with specific focus on empirical and epistemological perspectives. Journal of Clinical Nursing, 16 (8), 1405-1416. Doi: https://doi.org/10.1111/j.1365-2702.2006.01749.x

Act No. 420/2004 Coll. on mediation and amending certain laws.(In Slovak) Bratislava.

Bieleszová, D. (2017). School and peer mediation. (In Slovak) Bratislava: Wolters Kluwer.

Bingham, L.B. (2004). Employment dispute resolution: The case for mediation. Conflict Resolution Quarterly,22 (1-2), 145-174

BIS (Department of Business, Innovation and Skills) (2011). Resolving Workplace Disputes: A Consultation. London: BIS

Blake, R. R., \& Mouton, J. S. (1964). The managerial grid. Houston. Houston, TX: Gulf Publishing Company.

Budjač, M., Šimonová, K. \& Lazíková, J. (2014).Mediation Act. Comment. (In Slovak) Bratislava: Wolters Kluwer. 
Chamber of mediators and facilitators. (n.d.) https://www.kmfcr.cz/komora.html (accessed on 8 November 2018).

Cranet (2017). International Executive Report 2017, Cranet Survey on Comparative Human Resource Management. Cranfield: Cranet-Cranfield University.

DeChurch, L. A. and Marks, M. A., (2001). Maximizing the benefits of task conflict: The role of conflict-management. The International Journal of Conflict-management, 12(1), 422. Doi: https://doi.org/10.1108/eb022847

Elgoibar,P., Francisco J. Medina,J.F., Garcia,A., Pender,R.E. and Euwema,C.M. (2019). Mediation and conciliation in collective labor conflicts in europe: a cross cultural analysis. In.Euwema,C.M, Medina,J.F. García,B.A. \& Pender,R.E.(2019). Mediation in Collective Labor Conflicts (Industrial Relations \& Conflict Management). (pp. 227-244) Berlin: Springer Publishing House.

Filler, W. (2012). Commercial Mediation in Europe. An empirical Study of the User Experience. Netherland: Kluwer Law International.

Glasl, F. (1982) The process of conflict escalation and roles of third parties, In. G. B. J. Bomers a R. B. Peterson, (eds) Conflict-management and industrial relations, (pp. 119140) The Hague: Kluwer Nijhoff Publishing.

Griffin, W.R. (2010). Management. Mason: South-Western Cengage Learning.

Mediation center (In Czech) (2018, November). History of mediation in the Czech Republic. Retrieved from http://www.mediace-brno.cz/historie-azkusenosti.html

Holá, L. (2011). Mediation in theory and practice. (In Czech) Praha: Grada Publ. (In Czech)

Holá, L. (2015). Practical aspects of mediation in the Czech Republic. (In Czech). Retrieved November 8，2018, from https://www.pravniprostor.cz/clanky/ostatnipravo/prakticke-aspekty-mediace-v-cr

List of mediators. (In Czech). Retrieved November 8, 2018 from http://mediatori.justice.cz/MediatorPublic/Public/FR003_ZverejneniVybranychUdaju.aspx

Jehn, K. A. (1997). A Qualitative Analysis of Conflict Types and Dimensions in Organisational Groups. Administrative Science Quarterly, 42(3), 530-557. Doi: https://doi.org/10.2307/2393737

Jordan, T., (2000). Glasl's Nine-Stage Model Of Conflict Escalation. Retrieved January 24, 2019, from https://www.researchgate.net/publication $/ 265452970$ Glasl $\% 27 \mathrm{~s}$ NineStage Model Of Conflict Escalation

Rössel, J. (2013). Conflict Theory. Oxford: Oxford University Press.

Kathman, Mc., J. \& Kathman, D.M.(1990). Conflict management in the academic library. Journal of Academic Librarianship. 16 (3), 145-149. 
Katz, D. \& Kahn, R. L., (1966).The social psychology of organisations. New York: Wiley. Kelly, J. (1970). Making conflict work for you. Harvard Business Review, 48(4), 103-113. Kressel, K. (2006). Mediation revisited. M. Deutsch and P. Coleman (eds). The Handbook of Constructive Conflict Resolution: Theory and Practice. San Francisco: Jossey Bass.

Kuhn, T. \& Poole, M. S., (2000). Do conflict-management styles affect group decision making? Human Communication Research, 26(4), 558-590. Doi: https://doi.org/10.1111/j.1468-2958.2000.tb00769.x

Kutlík, F. (2017).Mediation in healthcare. (In Slovak) Bratislava: Wolters Kluwer.

Kutlík, F. (2008). Possibilities of mediation in self-government or from a mayor to mediator. (In Slovak) Bratislava: Jaspis.

Kurtzberg, T.S., \& Muller J.S. (2005). The influence of daily conflict on perceptions of creativity: A longitudinal study. International Journal of Conflict-management., 16(4), 335-353.

Lovász, G. (2009). Effectiveness and acceptition of labor mediation and reconciliation from the perspective of the social partners. (In Hungarian) Budapest: Budapesti Corvinus Egyetem

Lux, J. (2014). Labor relations, conflict-management and protection - practice oriented training with lessons. (In Hungarian) Hungarian Labor Review, 58(6), 99-104.

Mareschal, P.M. (1998). Providing high quality mediation insights from the federal mediation and conciliation service. Review of Public Personnel Administration, 18(4), 5567. Doi: https://doi.org/10.1177/0734371X9801800405

Mareschal, P. M. (2005). What makes mediation work? Mediators' perspectives on resolving disputes. Industrial Relations: A Journal of Economy and Society, 44(3), 509517. Doi: https://doi.org/10.1111/j.0019-8676.2005.00397.x

Mastenbroek, W. F. G. (1991).Conflict-management and Organizational Development. (In Hungarian) Budapest: Development, Economics and Law Publisher.

Mediation and Probation Center. (2016). Probation and Mediation Praxissurvey. (In Slovak). Prešov: Greek-Catholic Theological Faculty of the University of Presov.

Mediation Law 202/2012. Retrieved November 8, 2018, from http://www.amcr.cz/dokumenty/hp/A120620 VR_202_2012_MEDIACE.pdf

Mika Á. (2018). Practical application of the provisions of the new Civil Procedure Code in company disputes. (In Hungarian). Retrieved November, 15, 2018, from http://ptk2013.hu/szakcikkek/mika-agnes-az-uj-polgari-perrendtartas-rendelkezeseinekgyakorlati-alkalmazasa-a-tarsasagi-jogvitakban-ch-20187-3-10-o/6593

Mediation Law 202/2012 Sb, (In Czech). Retrieved November, 20, 2019, from https://www.zakonyprolidi.cz/cs/2012-202 
Moore, W. Ch. (2003). The Mediation Process: Practical Strategies for Resolving Conflict. Jossey-Bass: San Francisco.

Morasso, S. G. (2011). Argumentation in Dispute Mediation. A reasonable way to handle conflict. Amsterdam. The Netherlands: John Benjamins Publishing Co..

Morley, J. M., Poor, J., Heraty, N., Ruth, A. \& Pocztowski, A. (2015). Developments in human resource management in Central and Eastern Europe in Comparative Perspective. In Dickmann, M.,Brewster, Ch.\&Sparrow, P.. International Human Resource Management. Contemporary HR Issues In Europe. New York:Taylor-Francis.

Mrázek, P. (2012). Applying mediation in civil law. (In Slovak) Sládkovičovo: Danibius University.

National Mediation Association Statutes (2006). (In Hungarian). Retrieved November 15, 2018, from http://www.mediacio.hu/wp-content/uploads/2018/10/alapszabaly2006.pdf

Olson-Buchanan, J. \& W. Boswell, (2008). An Integrative Model of Experiencing and Responding to Mistreatment at Work. Academy of Management Review, 33 (1), 76-96. Doi: https://doi.org/10.5465/amr.2008.27745325

Patterson, K., Grenny, J. \& McMillan, R. (2011). Crucial Conversations Tools for Talking When Stakes Are High. New York: McGraw-Hill.

Partial evaluation of pilot phase of MIT Project for out-of-court resolution of consumer disputes for 2008. Retrieved November 20, 2018 from https://www.mpo.cz/en/consumerprotection/alternative-dispute-resolution-adr/partial-evaluation-of-pilot-phase-of-mitproject-for-out-of-court-resolution-of-consumer-disputes-for-2008--57761/

PDCS official website https://www.pdcs.sk/sk/o-nas (accessed on 9 September 2019).

Potocnik, K., Chaudhry, S. \& Bernal-Valencia, M. (2019). Mediation and Conciliation in Collective Labor Conflicts in the United Kingdom. In.Euwema,C.M, Medina,J.F. García,B.A. \& Pender,R.E.(2019). Mediation in Collective Labor Conflicts (Industrial Relations \& Conflict Management).(pp. 209-227) Berlin: Springer Publishing House.

Pruitt, D. G. (1983). Strategic choice in negotiation. American Behavioral Scientist. 27(2), 167-194. Doi: https://doi.org/10.1177/000276483027002005

Pružinská, J. (2007).The practice of mediation in Slovakia. (In Slovak), Bratislava:

Rahim, M. A., (2002). Toward a theory of managing organisational conflict. The International Journal of Conflict-management, 13(3), 206-235. Doi: https://doi.org/10.1108/eb022874

Riskin, L. L., (1984). Mediator Orientations, Strategies and Techniques, Alternatives, Harvard Negotiation Law Review, 7. 23-4.

Seargeant, J. (2005). The ACAS Small Firms Mediation Pilot: Research to Explore Parties' Experiences and Views on the Value of Mediation. ACAS Research Paper, 04/05 
Saundry, R., L. McArdle \& P. Thomas, (2013). Reframing Workplace Relations? Conflict Resolution and Mediation in a Primary Care Trust. Work, Employment and Society. 27(2), 221-239. Doi: https://doi.org/10.1177/0950017012472236

Stone, D., Patton, B. \& Sheila, S. H. (2000). Difficult Conversations: How to Discuss What Matters Most. Penguin Books.

Strasser, F. \& Randolph, P., (2008). Psychology of Conflict Resolution Mediation. (In Hungarian) Budapest: OpenBook Workshop.

Swanová, B., Baliová, D. \& Dolanská, R. (2016).The practical legal guide on mediation. (In Slovak) Bratislava: Wolters Kluwer.

The course of mediation. (In Hungarian). Retrieved November, 11, 2019, from http://www.mediatorkamara.hu/AMediacioMenete

Thomas, K. W. \& Kilmann, R. H., (2008).Thomas-Kilmann Conflict Mode Instrument Profile and Interpretive Report. Xicom: CCP Inc.

Treacy, G. C. (1948). Mediator Dei - Encyclical Letter of Pope Pius XII on the Sacred Liturgy. Mahwah: Paulist Press.

Yasmi,Y., Schanz,H. \& Salim, A. (2006). Manifestation of conflict escalation in natural resource management. Environmental science \& policy, 9, 538-546. Doi: https://doi.org/10.1016/j.envsci.2006.04.003

Yusuf, A. S., Pretorius, J. H. C. (2017). Conflict-management in projects. IEEE AFRICON Conference - Science, Technology and Innovation for Africa. 817-823.

Website of National Mediation Association. (In Hungarian) http://www.mediacio.hu/. (accessed on 15 November 2018). 